\title{
KEBIJAKAN PEMBIAYAAN BAGI NELAYAN TRADISIONAL
}

\author{
Rouli Anita Velentina \\ Fakultas Hukum, Universitas Indonesia \\ J1. Prof. Mr Djokosoetono, Kota Depok, Jawa Barat 16424 \\ vnapitupulu@yahoo.com
}

\begin{abstract}
Fishermen in Indonesia generally live in poverty line. This is an irony because fisheries management should be able to provide the greatest benefit for the improvement of people's prosperity. The definition of "people's welfare" primarily improves the living standard of traditional fishermen. Fishermen have several stereotypes, namely weak, ignorant, inefficient and unable to have plan for the future. These stereotypes influence various Government policies for fishermen communities. Therefore, it is important to analyse the financing policy for traditional fishermen. The research method used is normative juridical method. There are some conclusions. Firstly, the interest of banking institutions to grant credit facility to traditional fishermen is still minimum. Under the existing laws and regulations, the grant of credit facility for traditional fishermen could be classified as a high-risk credit facility. Secondly, to increase the interest of banking insitutions, the Government plays an important role.
\end{abstract}

Keywords: policy, financial institution, traditional fishermen.

\begin{abstract}
Abstrak
Para nelayan di Indonesia umumnya hidup dalam garis kemiskinan. Hal ini merupakan suatu ironi sebab pengelolaan perikanan seharusnya mampu memberikan keuntungan dan manfaat sebesar-besarnya bagi peningkatan kesejahteraan rakyat. Pengertian "kesejahteraan rakyat" utamanya meningkatkan taraf hidup nelayan tradisional. Masyarakat nelayan menyandang stereotip berupa lemah, bodoh, tidak efisien dan tidak mampu merencanakan masa depan. Stereotip tersebut memengaruhi berbagai kebijakan Pemerintah bagi masyarakat nelayan. Oleh karena itu, penting untuk menelaah kebijakan pembiayaan bagi para nelayan tradisional. Metode penelitian yang digunakan adalah metode yuridis normatif. Ada beberapa simpulan yang diperoleh. Pertama, minat lembaga perbankan untuk memberikan pinjaman kepada nelayan tradisional masih minim. Berdasarkan ketentuan yang berlaku, pemberian kredit bagi para nelayan tradisional dapat digolongkan sebagai pemberian kredit yang berisiko tinggi. Kedua, untuk meningkatkan minat lembaga perbankan, Pemerintah memegang peranan penting.
\end{abstract}

Kata kunci: kebijakan, lembaga keuangan, nelayan tradisional.

\section{A. Pendahuluan}

Para nelayan di negara berkembang umumnya hidup dalam garis kemiskinan dengan kesejahteraan yang minim (Hoorweg, 2009). Demikian pula halnya di
Indonesia. Dari keseluruhan penduduk miskin nasional, 25,14 persen adalah kaum nelayan (Probotanoyo, 2014) .

Keadaan tersebut merupakan suatu ironi sebab berdasarkan Pasal 2 Undang- 
Undang No.31 Tahun 2004 tentang Perikanan sebagaimana diubah dengan Undang-Undang No.45 Tahun 2009 (UU Perikanan), pengelolaan perikanan dilaksanakan dengan berdasarkan asas manfaat. Penjelasan Pasal 2 huruf a menjelaskan asas manfaat sebagai "asas yang menunjukkan bahwa pengelolaan perikanan harus mampu memberikan keuntungan dan manfaat yang sebesarbesarnya bagi peningkatan kemakmuran dan kesejahteraan rakyat." Dengan menilik secara cermat Pasal 3 huruf a UndangUndang No.31 Tahun 2004 tentang Perikanan, pengertian "kesejahteraan rakyat" ditujukan utamanya untuk meningkatkan taraf hidup nelayan tradisional.

Selain itu, perikanan merupakan salah satu sektor yang memberikan sumbangan besar terhadap devisa Negara. Sektor perikanan mampu menyumbang deflasi saat inflasi disumbang oleh hampir seluruh komoditas yang tergolong kelompok bahan makanan (Kadir, 2014). Bahkan, sektor perikanan ditargetkan untuk menjadi salah satu penyumbang besar bagi pendapatan Negara (Republik Indonesia, 2015).

Status masyarakat miskin, seringkali dilekatkan pada masyarakat nelayan, khususnya nelayan tradisional. Tidak hanya itu, masyarakat nelayan juga menyandang stereotip berupa lemah, bodoh, tidak efisien dan tidak mampu merencanakan masa depan. Stereotip tersebut memengaruhi berbagai kebijakan Pemerintah dalam menyusun program pembangunan ekonomi bagi masyarakat nelayan (Nadjib, 2013). Oleh karena itu, penting untuk ditelaah bagaimana stretegi kebijakan pembiayaan bagi para nelayan tradisional di Indonesia?

\section{B. Metode Penelitian}

Metode penelitian yang digunakan dalam penelitian ini adalah metode yuridis normatif. Alhasil, penelitian ini mengacu pada aturan hukum, prinsip-prinsip hukum maupun doktrin-doktrin hukum. Di Indonesia, penelitian yuridis normatif kerap kali dikenal dengan terminologi "penelitian hukum doktrinal". Penelitian hukum doktrinal atau yang dikenal dengan pendekatan "black-letter law" bertujuan untuk "systematise, rectify and clarify the law on any particular topic by a distinctive mode of analysis to authoritative texts that consist of primary and secondary source." Salah satu asumsinya adalah bahwa "the character of legal scholarship is derived from law itself'.

\section{Hasil dan Pembahasan}

Nelayan tradisional atau nelayan kecil (small-scale fisherman) memiliki karakteristik yang berbeda dengan karakteristik nelayan modern nelayan skala 
besar (large-scale fisherman) (Satria, 2011). Pasal 1 angka 11 UU Perikanan mengategorikan nelayan sebagai nelayan tradisional ketika menggunakan perahu berukuran paling besar 5 gross ton (GT). Jika nelayan modern, secara relatif, lebih padat modal, tidak demikian halnya dengan nelayan tradisional. Nelayan tradisional, pada umumnya, bersifat padat karya (Elfindri, 2002). Alhasil, pendapatan nelayan tradisional tidaklah setinggi nelayan modern.

Para nelayan tradisional melakukan $\mathrm{k}$ egiatan melaut yang umumnya merupakan kegiatan turun-temurun. Para nelayan tradisional melakukan kegiatan utama sebagai nelayan umumnya disebabkan kegiatan utama orang tua mereka adalah sebagai nelayan. Pada komunitas nelayan tradisional, pertimbangan status turuntemurun lebih berperan dibandingkan pertimbangan ekonomi. Sementara itu, pertimbangan ekonomi lebih memengaruhi perkembangan komunitas nelayan modern. Bertambahnya permintaan pasar atas protein yang berasal dari sumber daya laut yang menjadi faktor utama bertambahnya jumlah nelayan modern. Selain itu, orientasi nelayan modern menangkap ikan berbeda dengan orientasi nelayan tradisional menangkap ikan. Orientasi nelayan modern menangkap ikan adalah untuk menghasilkan ikan kaleng dan ikan beku yang berorientasi ekspor. Sementara itu, orientasi nelayan tradisional menangkap ikan semata-mata untuk memenuhi kebutuhan sehari-hari (Elfindri, 2002).

Dengan orientasi tersebut, para nelayan tradisional seringkali disebut sebagai peasant fisher. Mereka tidak berorintasi untuk menginvestasikan kembali hasil melaut mereka. Bahkan, pada umumnya, mereka merupakan kelompok termiskin dalam masyarakat. Meskipun demikian, mereka tetap memilih menjadi nelayan sebab menjadi nelayan bukan hanya sebagai mata pencaharian mereka (livelihood) tetapi telah menjadi jalan hidup mereka (way of life) (Satria, 2011).

\section{Penggolongan Nelayan Tradisional}

Berdasarkan kepemilikan alat produksi, nelayan tradisional umumnya terbagi menjadi dua. Pertama, nelayan pemilik alat produksi. Kedua, nelayan yang bertugas sebagai nelayan buruh. Nelayan pemilik alat produksi biasanya disebut sebagai nelayan juragan. Alat produksi dimaksud dapat berupa perahu, mesin perahu maupun alat penangkapan ikan. Nelayan juragan biasanya mempekerjakan atau merekrut nelayan lain dalam melakukan penangkapan ikan. Namun, ada juga nelayan pemilik perahu yang melakukan kegiatan menangkap ikan seorang diri menggunakan perahu miliknya. Para nelayan ini juga dikategorikan sebagai nelayan juragan. 
Kedua, nelayan yang bertugas sebagai nelayan buruh. Nelayan buruh, atau yang biasanya disebut dengan pandega, merupakan nelayan yang memiliki kemampuan menangkap ikan namun tidak memiliki alat produksi. Tanpa alat produksi, tidak mungkin nelayan buruh melakukan kegiatan penangkapan ikan. Itulah sebabnya para nelayan buruh menjual tenaga dan keahlian melaut mereka kepada nelayan juragan (Imron, 2002).

Selain berdasarkan kepemilikan alat produksi, para nelayan tradisional juga dapat dikelompokkan berdasarkan status kenelayanan. Yang dimaksud dengan status kenelayanan adalah asal usul nelayan yang bersangkutan. Berdasarkan status kenelayanan, nelayan dapat dikelompokkan menjadi dua. Pertama, nelayan lokal daerah tersebut. Kedua, nelayan pendatang (Imron, 2002) .

\section{Sejarah Kebijakan Pembiayaan bagi Nelayan Tradisional}

Terdapat beberapa faktor yang menyebabkan kemiskinan para nelayan tradisional. Pertama, faktor teknis. Faktor teknis ini terdiri atas wilayah penangkapan ikan yang terbatas; penurunan produksi ikan sebagai akibat kerusakan ekosistem dan perubahan iklim; pengolahan hasil tangkapan ikan kurang tepat, sehingga mutu ikan menurun; minimnya ketersediaan tempat pendingin ikan, sehingga mutu ikan tidak terjaga; terjerumus pinjaman dari rentenir; ketidakstabilan harga ikan; mahalnya biaya untuk memberli perlengkapan melaut dari pedagang perantara; harga jual BBM; dan sistem bagi hasil belum memadai. Kedua, faktor kultural. Yang dimaksud dengan faktor kultural adalah faktor berkaitan dengan etos kerja nelayan yang tidak sejalan dengan perkembangan zaman. Ketiga, faktor struktural. Faktor struktural ini berkaitan dengan kebijakan dan program Pemerintah yang tidak kondusif bagi kesejahteraan nelayan.

Pemerintah Indonesia, pada tahun 1970an, melakukan kebijakan penyaluran berbagai macam kredit dalam jumlah besar untuk mencapai swasembada pangan dan meningkatkan devisa dari sektor perikanan. Terjadi perkembangan luar biasa pada sektor pertanian pangan yang dikenal dengan istilah "revolusi hijau" dan pada sektor perikanan tambak yang dikenal dengan istilah "revolusi biru". Akan tetapi, penyaluran kredit untuk sektor perikanan tangkap tidak pernah dilakukan (Nadjib, 2013).

Para nelayan tradisional perikanan tangkap membutuhkan dana besar untuk memiliki perahu, mesin perahu, jaring dan biaya operasional penangkapan. Sementara itu, nelayan sulit memperoleh pembiayaan 
dari bank. Lembaga keuangan formal tidak berminat untuk menyalurkan kredit kepada sektor perikanan tangkap. Pada tahun 1980, dilaksanakan Kredit Bimbingan Massal (Bimas) kepada nelayan. Namun, penyaluran kredit ini mengalami hambatan. Angsuran pembayaran kredit tidak dipenuhi dengan baik oleh banyak nelayan. Kredit ini pun akhirnya dihentikan. Sejak saat itu, penyaluran kredit kepada sektor perikanan tangkap tidak diminati oleh lembaga keuangan formal. Berdasarkan data Bank Indonesia, dalam kurun waktu 2005-2009, kredit untuk perikanan hanya mengalami kenaikan 0,01 persen dari total kredit perbankan, yakni dari 0,22 persen menjadi 0,23 persen. Pada tahun 2009, kredit bermasalah di sektor perikanan mencapai 11,76 persen (Nadjib, 2013).

Penyaluran kredit kepada nelayan tangkap sudah sejak masa pemerintahan Hindia Belanda tidak diminati oleh lembaga keuangan formal. Pada masa itu, kredit hanya disalurkan kepada sektor perikanan budi daya. Pada tahun 1907, surat edaran tentang penyaluran kredit untuk usaha pertambakan dan penangkapan ikan dikeluarkan oleh Pemerintah Hindia Belanda. Pemerintah Belanda, kemudian, mempersiapkan sepuluh bank sebagai pelaksana kredit rakyat (volkscredietwezen) tersebut di sepanjang pantai utara Jawa dan Madura. Dalam pelaksanaannya, penyaluran kredit hanya dilakukan untuk pembudi daya ikan. Bank hanya bersedia memberikan kredit kepada nelayan ketika terpenuhi agunan yang memadai. Bahkan, pada saat Visscherij Station (Kantor Perikanan) didirikan di Jakarta dan Afdeeling Visscherij (Dinas Perikanan) dibentuk di lingkungan Departemen Pertanian oleh Pemerintah Hindia Belanda, penyaluran kredit bagi nelayan tradisional hampir tidak pernah dilaksanakan (Nadjib, 2013).

\section{Strategi Kebijakan Pembiayaan bagi Nelayan Tradisional}

Pada pasal 60 ayat (1) huruf b Undang-Undang No.31 Tahun 2004 tentang Perikanan, disebutkan bahwa pemberdayaan nelayan kecil dilakukan dengan penyelenggaraan pendidikan, pelatihan, dan penyuluhan bagi nelayan kecil serta pembudi daya ikan kecil untuk meningkatkan pengetahuan dan keterampilan di bidang penangkapan, pembudidayaan, pengolahan, dan pemasaran ikan.

Penyelenggaraan pendidikan, pelatihan dan penyuluhan merupakan ujung tombak pemberdayaan. Tujuan dari pemberdayaan adalah menciptakan kemandirian, meningkatkan produktivitas usaha, dan kesejahteraan nelayan tersebut. Pada dasarnya, para nelayan telah memiliki bekal pengetahuan lokal (local knowledge) yang didapat secara turun menurun. 
Pengetahuan lokal tersebut hendaknya digabungkan dengan ilmu pengetauan dan teknologi (Toha-Sarumpaet, 2007) .

Suntikan modal bagi nelayan merupakan suatu hal yang penting. Dalam usaha pengembangan nelayan tradisional, Pemerintah Negara Kenya melakukan upaya-upaya yang bertujuan agar hasil tangkapan nelayan tersebut meningkat serta pengembangan strategi pemasaran. Dengan meningkatnya jumlah hasil tangkapan dan pengembangan strategi pemasaran, maka kesejahteraan nelayan lokal akan ikut meningkat seiring dengan meningkatnya pendapatan. Pada tahun 1970-1974, Pemerintah Negara Kenya mengeluarkan dana sebesar $£ 10.000$ untuk bantuan finansial bagi nelayan yang menangkap ikan dekat pantai. Pemberian dana tersebut berdampak pada meningkatnya pendapatan Negara Kenya dalam bidang penangkapan ikan dekat pantai menjadi $£ 224.000$. Meningkatnya pendapatan negara dalam sektor perikanan, membuat Pemerintah Negara Kenya menggelontorkan dana sebesar $£ 1,6$ juta untuk pendanaan tetap bagi nelayan dan $£ 1$ juta untuk pengembangan nelayan (Hoorweg, 2009). Hal tersebut menunjukkan bahwa peran pemerintah dalam bidang pendanaan merupakan hal yang penting dalam peningkatan hasil tangkapan serta kesejahteraan nelayan.
Pemerintah Negara Indonesia sendiri telah memiliki langkah-langkah dalam pengembangan sektor perikanan. Pemerintah Negara Indonesia telah membentuk komite khusus yang berfokus dalam bidang perikanan. Dalam Pasal 7 ayat (5) UU Perikanan, disebutkan bahwa akan dibentuk komite nasional yang beranggotakan para ahli dalam bidangnya yang berasal dari lembaga terkait. Para ahli ini terdiri dari pakar; akademisi; dan pejabat instansi pemerintah yang memiliki keahlian di bidang sumber daya ikan. Dalam hal ini, komite perikanan tersebut memberikan rekomendasi kepada Menteri mengenai potensi dan alokasi sumber daya ikan di wilayah pengelolaan perikanan serta jumlah tangkapan yang diperbolehkan di wilayah pengelolaan perikanan negara.

Selain pembentukan Komite Perikanan, Pemerintah Negara Indonesia juga memiliki kebijakan lain, salah satunya dalam pembiayaan bagi nelayan. Dilihat dari sumbernya, terdapat beberapa jenis sumber pembiayaan atau kredit dari lembaga pembiayaan formal yang dapat diakses oleh usaha perikanan tangkap. Pembiayaan tersebut yakni: 1) Pembiayaan melalui lembaga koperasi; dan 2). Pembiayaan dari sektor perbankan. 


\section{Pembiayaan melalui Lembaga Koperasi}

Pada tahun 2000-2003, Pemerintah Negara Indonesia melaksanakan Program Pemberdayaan Ekonomi Masyarakat Pesisir (PEMP). Dana ini berasal dari APBN melalui Kementrian kelautan dan Perikanan. Penyaluran dana dilakukan oleh Swamitra Mina dengan persyaratan yang mudah, namun bunga yang diberikan lebih tinggi dari bunga bank. Kemudian Pada tahun 2006, Pemerintah melaksanakan program Pengembangan Ekonomi Masyarakat Pesisir (PEMP) dalam rangka untuk menyejahterakan masyarakat pesisir. Program ini merupakan pelaksanaan Keputusan Menteri Kelautan dan Perikanan No.18/Men/2004 dan Keputusan Dirjen Kelautan Pesisir dan Pulau-pulau Kecil No.SK07/KP3K/I/2006, tanggal 26 Januari 2006. Pemerintah memberi dana hibah kepada Koperasi Nelayan yang dikenal dengan Dana Penguatan Modal (DPM) Koperasi Nelayan. Kemudian, Direktorat Jenderal Kelautan Pesisir dan Pulau-pulau Kecil (KP3K) Departemen Kelautan dan Perikanan dan Bank Rakyat Indonesia menandatangani perjanjian kerjasama No.K.14/KP3K-BRI/VII/05 dan B.530Dir/PRG/07/2005, tanggal 18 Juli 2005. Pemerintah mengadakan kerjasama dengan lembaga perbankan agar bank menyalurkan pinjaman kepada para nelayan dengan agunan dana hibah tersebut (Nuryahman, 2014)

Pada tahun 2006/2007, penyaluran dana dilakukan oleh Koperasi Mikro (Nadjib, 2013). Program Program Pemberdayaan Ekonomi Masyarakat Pesisir ini mengalami kegagalan, hal ini disebabkan tidak sesuainya kebijakan yang dirancang dalam garis panduan PEMP dengan pelaksanaan di lapangan. Penyebab utama kegagalan program ini adalah kurangnya pengawasan serta konsultan manajemen yang tidak memiliki sasaran yang jelas. Sulitnya akses, tidak dibaginya Sisa Hasil Usaha (SHU), serta tidak tepatnya pemberian kredit, juga menjadi faktor gagalnya program ini (Nadjib, 2013).

Pada pasal 60 ayat (1) huruf c Undang-Undang No.31 Tahun 2004 tentang Perikanan, menjelaskan bahwa Pemerintah memberdayakan nelayan kecil dan pembudidaya ikan kecil melalui penumbuhkembangan kelompok nelayan kecil, kelompok pembudidaya ikan kecil, dan koperasi perikanan. Untuk mengembangkan suatu institusi ekonomi di kalangan nelayan serta menciptakan ketahanan ekonomi untuk menghadapi perubahan dari luar, dibutuhkan suatu kelompok nelayan yang solid (TohaSarumpaet, 2007)

Dengan adanya suatu kelompok nelayan yang solid, maka pemenuhan atas 
hak-hak nelayan akan lebih mudah diakses. Proses advokasi kepada pemerintah juga akan lebih berdampak besar karena disuarakan oleh banyak orang. Pemberdayaan ekonomi nelayan melalui lembaga koperasi, selayaknya didasarkan pada prinsip-prinsip yang sejiwa dengan cita-cita koperasi sebagaimana tercantum dalam Pasal 33 UUD 1945 (Afdol et.al, 2007). Perkembangan Koperasi Perikanan berada dalam kondisi yang memperihatinkan. Masalah utama yang dihadapi adalah masalah permodalan. Koperasi umumnya bergantung pada simpanan pokok dan simpanan wajib dari anggotanya. Jumlah ini tidak mencukupi untuk memberikan pinjaman kepada nelayan. Padahal koperasi dapat menjadi salah satu jalan untuk memutus patron-klien antara rentenir dengan nelayan (Nadjib, 2013). Keberhasilan koperasi perikanan juga tidak terlepas dari peran kelompok nelayan di daerah tersebut. Budaya organisasi kelompok nelayan setempat akan sangat memengaruhi kemajuan koperasi perikanan yang ada di daerah tersebut (TohaSarumpaet, 2007).

Penyelenggaraan

pendidikan, pelatihan dan penyuluhan merupakan ujung tombak pemberdayaan. Tujuan dari pemberdayaan adalah menciptakan kemandirian, meningkatkan produktivitas usaha, dan kesejahteraan nelayan tersebut.
Pada dasarnya, para nelayan telah memiliki bekal pengetahuan lokal (local knowledge) yang didapat secara turun menurun. Pengetahuan lokal tersebut hendaknya digabungkan dengan ilmu pengetauan dan teknologi (Toha-Sarumpaet, 2007).

Saat ini, pemberdayaan nelayan juga sering dilakukan oleh Lembaga Swadaya Masyarakat serta pihak swasta juga ikut andil dalam pemberdayaan nelayan. Hal ini dikarenakan kondisi nelayan yang rata-rata berada dalam kemiskinan. Dengan meningkatnya pengetahuan nelayan dalam bidang penangkapan ikan, diharapkan proses penangkapan ikan menjadi lebih optimal dan pendapatan nelayan menjadi meningkat. Pemberdayaan yang dilakukan oleh masyarakat merupakan salah satu cara yang efektif. Akan tetapi untuk dapat melakukan pemberdayaan, masyarakat tersebut sebelumnya harus mendapat pemberdayaan terlebih dahulu (Elmiyah, 2012).

\section{Pembiayaan dari Sektor Perbankan}

Dalam pasal 60 ayat (1) UndangUndang No. 31 Tahun 2004 tentang Perikanan, disebutkan bahwa peran Pemerintah Negara Indonesia mencakup pemberdayaan nelayan kecil dan pembudi daya ikan kecil melalui penyediaan skim kredit. Skim kredit ini dapat digunakan untuk modal usaha, maupun biaya operasional dengan cara yang mudah, bunga 
pinjaman yang rendah, dan sesuai dengan kemampuan nelayan kecil dan pembudi daya ikan kecil.

Berkenaan dengan pengembangan nelayan tradisional perikanan tangkap, peraturan perundang-undangan dibidang perbankan pada hakekatnya telah mengakomodir hal tersebut. Pasal 12 UU Perbankan mengatur bahwa bank umum dapat ditugaskan untuk mengembangkan sektor-sektor perekonomian tertentu atau memberikan perhatian lebih besar kepada koperasi dan pengusaha ekonomi lemah/pengusaha kecil dalam rangka meningkatkan taraf hidup rakyat banyak. Ditegaskan dalam Rencana Pembangunan Jangka Menengah Nasional 2015-2019, pembangunan sektor perikanan sangatlah membutuhkan pendanaan lembaga perbankan dalam skema tertentu (Kementerian Perencanaan Pembangunan Nasional, 2014).

Pembiayaan usaha perikanan tangkap melalui sektor perbankan diberikan melalui Program Kredit Usaha Rakyat (KUR) dan Program Kredit Non-KUR. Dalam Program KUR, Pemerintah Negara Indonesia menargetkan penyaluran KUR sebesar Rp 20 triliun. Terkait KUR, pemerintah membuat kebijakan bahwa jika permohonan kredit kurang dari Rp 20 juta, maka nelayan tidak perlu memberi agunan, jaminannya adalah usaha nelayan itu sendiri. Dalam
KUR, pihak bank merupakan pelaksana dan pemberi dana, sedangkan Pemerintah berperan sebagai penjamin resiko KUR (Nadjib, 2013). Bank-bank yang telah aktif memberikan KUR antara lain Bank Jawa Timur dan Bank BRI.

Program Kredit Non-KUR merupakan kredit penguatan modal usaha perikanan tangkap. Program ini dilaksanakan oleh Bank Pembiayaan Rakyat Syariah (BPRS) Bhakti Sumekar, Sumenep. Pembentukan BPRS Bhakti Sumekar berawal dari pengambilalihan BPR Dana Merapi Sidoarjo oleh Pemerintah Kabupaten Sumenep pada tahun 2002. Pada tahun 2003, BPRS bekerjasama dengan enam dinas di lingkungan Kabupaten. Dinas Kehutanan dan Perikanan Sumenep mendapatkan dana pemberdayaan awal sebesar Rp 10 miliar. Dana tersebut kemudian disalurkan kepada nelayan di Kabupaten Sumenep oleh BPRS tersebut. Dalam hal ini, BPRS hanya berfungsi sebagai penyalur kredit. Jika terdapat kredit macet, maka BPRS dapat menarik deposito Pemerintah Kabupaten Sumenep yang berasal dari APBD (Nadjib, 2013).

Pemberian Kredit Non-KUR tersebut mengalami kemacetan. Nilai tunggakannya mencapai Rp 4,8 miliar. Kredit macet yang berada di dalam lingkup pengawasan Dinas Kelautan dan Perikanan mencapai 33\%. Besarnya nilai tunggakan mengakibatkan 
dihentikannya Program Kredit Non-KUR pada tahun 2007. Upaya penagihan tunggakan telah dilakukan hingga tahun 2011, namun hal ini tidak membuahkan hasil. Akhirnya penagihan tunggakan tersebut dialihkan ke pihak kejaksaan. Meskipun telah dialihkan ke pihak kejaksaan, upaya pelunasan terhadap kredit macet tetap gagal (Nadjib, 2013).

Setelah pemberian kredit tersebut mengalami kegagalan, BPRS Bhakti Sumekar mengeluarkan skema pembiayaan gadai emas. Skema pembiayaan dengan gadai emas mencapai keberhasilan dan tanpa tunggakan. Pada sistem gadai emas yang diterapkan pendapatan BPRS Bhakti Sumekar dapat mencapai Rp40 juta - Rp50 juta per harinya. Persyaratan yang mudah serta jasa ujrah yang didapatkan oleh BPRS tidaklah besar. Hal ini membuat nelayan tertarik untuk mendapatkan pembiayaan dari sistem ini (Nadjib, 2013).

BPR pesisir yang pertama di Indonesia adalah BPR Mutiara Pesisir yang terletak di Kabupaten Agam, Sumatera Barat. Selain BPR Mutiara Pesisir, terdapat juga BPR Samudera yang berada di Kabupaten Pesisir Selatan. BPR Mutiara Pesisir menjadi BPR pesisir percontohan nasional. BPR Mutiara Pesisir menjadi percontohan nasional karena tingginya peningkatan aset BPR Mutiara Pesisir. Peningkatan asetnya mencapai $158,17 \%$ dengan penyaluran dana kredit ke masyarakat sebesar $\mathrm{Rp}$ 7,1miliar. BPR Mutiara juga memiliki beberapa program unggulan untuk pemberdayaan masyarakat, yakni pemberian kredit dengan bunga yang bersaing serta kerjasama dengan lembaga lainnya (Kementerian Kelautan dan Perikanan, 2009). Pemberian kredit bagi nelayan juga diberikan oleh Bank milik pemerintah, diantaranya Bank Rakyat Indonesia dan Bank Pembangunan Daerah, namun prosesnya administrasinya sulit dan agunannya juga besar (Simarmata, 2012).

Di Provinsi Nusa Tenggara Barat (NTB) telah terdapat dua BPR pesisir, yakni BPR Perisir Akbar yang terletak di Kabupaten Bima, serta BPR Pesisir Layar Berkembang di Kabupaten Lombok Barat. Pembukaan BPR Pesisir tersebut merupakan upaya untuk memberikan akses perbankan kepada nelayan. Kedua BPR yang terdapat di NTB tersebut menunjukkan dampak yang positif. BPR Pesisir Akbar saat ini memiliki 1.600 nasabah, sementara BPR Layar Berkembang mengalami peningkatan total aset aktiva dari Rp713,3 juta menjadi Rp4,1 miliar (Kementerian Kelautan dan Perikanan, 2009).

Para nelayan di wilayah NTB merasa sangat terbantu dengan adanya kedua BPR tersebut. Para nelayan tak lagi pusing memikirkan modal. Pinjaman yang diberikan pun bunganya rendah, sehingga tidak memberatkan nelayan. BPR pesisir di 
wilayah NTB memiliki karakteristik yang cukup unik, selain membantu nelayan, BPR pesisir juga memberikan bantuan dana kepada peternak, petani, maupun pedagang. Hal ini dikarenakan bunga yang diberikan oleh rentenir cukup besar, yakni lebih dari $5 \%$, sedangkan bunga yang ditetapkan oleh BPR pesisir tidak lebih dari 3\%. Hal inilah yang membuat BPR Pesisir menjadi pilihan untuk mendapatkan pinjaman (Kementerian Kelautan dan Perikanan, 2009).

Jika dilihat dari perkembangan BPR Pesisir yang berada di NTB, maka pendirian BPR Pesisir di wilayah Nusa Tenggara Timur (NTT), terutama disekitar Kelurahan Oesapa dan Kelurahan Kelapa Lima merupakan prospek yang baik. Hal ini dapat dinilai dari letak Provinsi NTB yang berdekatan dengan Provinsi NTT. Dari segi ekonomi, sosial dan budaya, masyarakat NTT memiliki kemiripan dengan masyarakat NTB.

Selain itu, pembiayaan dari Bank bagi nelayan saat ini diatur dalam ketentuan Pasal 19 ayat (1) Undang-Undang No. 32 Tahun 2014 tentang Kelautan, disebutkan bahwa pihak perbankan bertanggung jawab dalam pendanaan suprastruktur usaha perikanan. Dalam hal ini berarti pihak bank bertanggung jawab atas pemberian dana bagi nelayan. Ketentuan lebih lanjut mengenai pendanaan suprastruktur tersebut akan diatur dalam undang-undang tersendiri.
Pendanaan suprastruktur sendiri merupakan skema yang berbeda dengan pendaan UMKM. Pendanaan suprastruktur tersebut dikhususkan untuk mengembangkan industri perikanan di Indonesia.

$$
\text { Indonesia telah mengeluarkan }
$$
Undang-Undang No. 32 Tahun 2014 tentang Kelautan pada tanggal 17 Oktober 2014. Pasal 19 Undang-Undang ini mengatur penyelesaian awal atas permasalahan nelayan memperoleh pinjaman untuk usaha penangkapan ikan. Ada dua hal penting yang diatur terkait pendanaan usaha perikanan. Pertama, Undang-Undang ini menegaskan tanggung jawab perbankan atas pendanaan sektor perikanan. Kedua, pendanaan usaha perikanan berupa pendanaan suprastruktur dan diatur dalam undang-undang tersendiri. Tidak ada penjelasan lebih lanjut tentang apa yang dimaksud dengan pendanaan suprastruktur.

Pengaturan pendanaan suprastruktur haruslah mengadopsi natur hukum perbankan, terutama terkait pemberian kredit oleh bank. Dalam suatu pemberian kredit atau pembiayaan, yang dibutuhkan adalah adanya jaminan; bank dapat memberikan kredit atau pembiayaan ketika bank memiliki keyakinan bahwa nasabah akan melunasi utangnya. Pengertian jaminan dalam perkreditan atau pembiayaan berbeda dengan pengertian agunan. Pasal 1 angka 23 Undang-Undang No. 7 Tahun 1992 tentang 
Perbankan sebagaimana telah diubah dengan Undang-Undang No.10 Tahun 1998 (“UU Perbankan") mengatur bahwa agunan adalah "jaminan tambahan yang diserahkan Nasabah Debitur kepada bank dalam rangka pemberian fasilitas kredit". Penjelasan Pasal 8 ayat (1) UU Perbankan menjelaskan bahwa jaminan berarti keyakinan atas kemampuan dan kesanggupan Nasabah Debitur untuk melunasi kewajibannya sesuai dengan yang diperjanjikan. Dengan demikian, pengertian terminologi hukum "jaminan" berbeda dengan pengertian terminologi hukum "agunan". Jaminan berarti bank memiliki keyakinan bahwa nasabah mampu dan sanggup untuk melunasi pinjaman sesuai dengan perjanjian yang disepakati. Sementara itu, agunan adalah jaminan tambahan, yakni suatu jaminan kebendaan yang memiliki nilai ekonomis atas pelunasan pembayaran pinjaman. Artinya, jaminan (kepercayaan) merupakan syarat mutlak untuk pemberian kredit, sedangkan, agunan sebagai syarat tambahan dan tidak diwajibkan.

Agunan tidaklah bersifat wajib. Meskipun demikian, penjelasan Pasal 8 (1) UU Perbankan menjelaskan bahwa Bank berkewajiban untuk melaksanakan analisis mendalam sebelum menyalurkan kredit atau memberikan pembiayaan sesuai dengan prinsip kehati-hatian. Kredit untuk usaha perikanan tangkap pun hanya dapat disalurkan setelah bank melakukan analisis mendalam sesuai dengan prinsip kehatihatian. Dengan perkataan lain, penilaian terhadap nasabah haruslah memenuhi prudential principle. Artinya, bank melakukan penilaian secara seksama terhadap nasabah yang meliputi watak, kemampuan, modal, agunan dan prospek usaha nasabah.

Sampai dengan saat ini, akses pembiayaan bagi nelayan tradisional, masih belum optimal. Sebagian besar kredit sektor kemaritiman masih diperuntukkan untuk perkapalan dan industri pengolahan. Berdasarkan penilaian Bank Indonesia, ada dua penyebab lembaga perbankan kurang berminat untuk menyalurkan pembiayaan ke sektor perikanan tangkap. Pemberian kredit untuk sektor perikanan tangkap dinilai lembaga perbankan memiliki risiko tinggi. Hal ini mengakibatkan penyaluran kredit kepada sektor perikanan tangkap mensyaratkan agunan dengan nilai ekonomis sebesar pinjaman. Selain itu, berdasarkan penilaian lembaga perbankan, persyaratan agunan yang ditetapkan bank sulit dipenuhi oleh para nelayan. Bank, pada umumnya, hanya menerima agunan berupa sertifikat tanah atau bukti pemilikan kendaraan bermotor (Nadjib, 2013). Bank umumnya berkeberatan menerima perahu sebagai agunan. Hal ini disebabkan perahu mudah untuk dibawa ke daerah lain dan dijual ke 
pihak lain . Akibatnya, para nelayan sulit memperoleh kesempatan untuk mendapatkan pinjaman dari bank untuk membeli perahu dan alat penangkapan ikan yang memadai.

Dapat dipahami apabila sulit bagi bank untuk bisa memiliki keyakinan terhadap masyarakat nelayan dalam hal pengembalian pinjaman. Pada masyarakat nelayan, ada stereotip buruk bahwa nelayan seringkali 'nakal' dalam pembayaran angsuran pinjaman. Selain itu, stereotip buruk lainnya yang melekat pada masyarakat nelayan adalah masyarakat miskin yang senang menghambur-hamburkan uang. Terlebih lagi, usaha perikanan tangkap merupakan usaha yang berisiko tinggi. Keberhasilan usaha ini ditentukan oleh faktor-faktor diluar kendali manusia, seperti kondisi cuaca. Kemudian, ikan tergolong dalam komoditas yang mudah rusak.

Apabila nelayan hendak memberikan agunan tambahan berupa perahu, setidaknya ada dua permasalahan yang dihadapi nelayan. Pertama, para nelayan akan menghadapi kesulitan memenuhi persyaratan administrasi, seperti halnya Surat Izin Usaha Perdagangan (SIUP) dan Nomor Pokok Wajib Pajak (NPWP). Kedua, nelayan tradisional tidak bisa menyerahkan perahu miliknya sebagai agunan sebab sertifikasi terhadap perahu sulit untuk dilakukan. Tidak ada standar baku pembuatan perahu-perahu. Perahu buatan suatu daerah tidak memiliki standar baku yang sama dengan perahu buatan daerah yang lain. Bobot yang sama tidak serta merta berarti bahan baku dan kualitas produksi sama.

\section{Simpulan dan Saran}

Berdasarkan hasil paparan di atas, dapat disimpulkan bahwa minat lembaga perbankan untuk memberikan pinjaman kepada nelayan tangkap masih minim. Oleh karena itu, untuk meningkatkan minat tersebut, Pemerintah memegang peranan yang besar.

\section{DAFTAR PUSTAKA}

\section{Buku}

Afdol et.al. (2007). Kajian Kearifan Lokal Masyarakat Nelayan Teluk Jakarta dalam Menghadapi Tekanan Globalisasi dan Urbanisasi: Studi Kasus Masyarakat Nelayan Tradisional di Cilincing dan Penjaringan. Jakarta: Universitas Indonesia.

Elfindri. (2002). Ekonomi "Patron-Client": Fenomena Mikro Rumah Tangga Nelayan dan Kebijakan mikro. Padang: Andalas University Press.

Elmiyah, N. et. a. (2012). Kajian Hukum terhadap Partisipasi Masyarakat dalam Pengelolaan Wilayah Pesisir dan Pulau-Pulau Kecil di Kepulauan 
Seribu. Jakarta: Universitas Indonesia.

Hoorweg, J. et. a. (2009). Artisanal Fishers on the Kenyan Coast: Household Livelihoods and Marine Resource Management. Leiden: Brill.

Imron, M. et. a. (2002). Pengelolaan Sumberdaya Laut secara Terpadu: Masyarakat Nelayan dan Negosiasi Kepentingan. Jakarta: PMB-LIPI (Puslit Kemasyarakatan dan Kebudayaan Lembaga Ilmu Pengetahuan Indonesia.

Kementerian Kelautan dan Perikanan. (2009). Profil Bank Perkreditan Rakyat Pesisir. Jakarta: Direktorat Jendral Kelautan Pesisir dan Pulau-Pulau Kecil, Kementerian Kelautan dan Perikanan.

Kementerian Perencanaan Pembangunan

Nasional. (2014). Rencana

Pembangunan Jangka Menengah

Nasional 2015-2019. Kementerian

Perencanaan Pembangunan Nasional.

Nadjib, M. (2013). Pendekatan Studi Sistem Pembiayaan Masyarakat Nelayan”, dalam Mochammad Nadjib, ed., Optimalisasi Pemanfaatan Sumber Daya Ekonomi Kelautan: Sistem Pembiayaan Nelayan. Jakarta: Universitas Indonesia.

Nuryahman, I. K. S. P. ; D. B. S. (2014).

Kajian Sejarah Sosial Masyarakat Nelayan di Pesisir Waingapu
Kabupaten Sumba Timur Provinsi Nusa Tenggara Timur. Yogyakarta: Penerbit Ombak.

Republik Indonesia. (2015). Nota Keuangan dan Anggaran Pendapatan dan Belanja Negara Tahun Anggaran 2015.

Satria, A. (2011). Dinamika Modernisasi Perikanan: Formasi Sosial dan Mobilitas Nelayan. Bandung: Humaniora Utama Press.

Simarmata, R. (2012). Indonesian law and reality in the Delta: a socio-legal inquiry into laws, local bureaucrats and natural resources management in the Mahakam Delta, East Kalimantan. Leiden: Leiden University Press.

Toha-Sarumpaet, R. K. et. a. (2007). Pembangunan Perdesaan dan Daerah Pesisir pada Era Milenium III. Jakarta: UI Press.

\section{Artikel dalam Surat Kabar}

Kadir. (2014). Menteri Susi dan Konsumsi Ikan. Koran Tempo.

Probotanoyo, D. (2014, April 10). Menyejahterakan Nelayan. Republika. 